\title{
EFFECT OF FOLIAR SPRAY WITH HUMIC ACID AND GREEN MICROALGAE EXTRACT ON GROWTH AND PRODUCTIVITY OF GARLIC PLANT GROWN IN SANDY SOIL
}

\author{
E.E. Abou El-Khair ${ }^{1}$, I.A.S. Al-Esaily ${ }^{1}$ and H.E.M. Ismail ${ }^{2}$ \\ ${ }^{1}$ Hort. Research Institute, Agriculture Research Center, Giza, Egypt. \\ ${ }^{2}$ Hort. Department, Faculty of Agriculture, Zagazig University, Egypt.
}

\section{ABSTRACT:}

The present work was carried out in vegetable private farm at El-Kassasein Distract, Ismailia governorate during two successive winter seasons of 2008/2009 and 2009/2010, to evaluate the effect of foliar spray with both humic acid (HA) at 0, 0.1and $0.2 \%$ and green microalgae extract (GMAE) of Scenedesmus sp. at 0, 0.1 and $0.2 \%$ as well as their interactions on nutrient content and uptake as well as photosynthetic pigments. Consequently, growth and yield of garlic (sids40) under sandy soil conditions using drip irrigation system.

Spraying garlic plants with $H A$ at $0.2 \%$ or with GMAE at $0.2 \%$ recorded the maximum values of N,P and $K$ uptake in bulb and N,P and $K$ total uptake, chlorophyll $a, b$, total $(a+b)$ and carotenoids, total dry weight, average bulb weight, yield of grades 1 and 2 and total yield/fed. without significant differences by spraying with GMAE at $0.1 \%$ with respect yield and its components.

The interaction between spraying of garlic plants with HA at 0.2 $\%$ and GMAE at $0.1 \%$ was the best interaction treatment for enhancing N,P and $K$ total uptake, total dry weight, while average bulb weight, yield of grades 1 and 2 and total yield/fed. were increased with the interaction between HA at $0.2 \%$ and GMAE at 0.1 or $0.2 \%$.

Conclusively, from foregoing results of this study, it could be concluded that spraying of garlic plants with HA at $0.2 \%$ and GMAE at $0.2 \%$ increased mineral uptake, plant growth and total yield of garlic under sandy soil conditions.

Keywords : Garlic, humic acid, green microalgae extract, NPK uptake and total yield.

\section{INTRODUCTION}

Garlic (Allium sativum L.) is the second most important crop cultivated and used among Alliums after onion. It is consumed as fresh as well as dried in the spice form and as an ingredient to flavour the various dishes all over the world. It is also medicinally important. 
Application of humic acids (HA) has several benefits and agriculturists all over the world are accepting HA as an integral part of their fertilizer program. It can be applied directly to the plant foliage in liquid form or to the soil in the form of granules alone or as fertilizer mixture. Humic acid is one of the major components of humus. Humates are natural organic substances, high in HA and containing most of known trace minerals necessary to the development of plant life (Senn, 1991).

Foliar application of HA (25\% active HA) consistently enhanced antioxidants such as $\alpha$ - tocopheral, $\beta$-carotene, superoxide dismutases, and ascorbic acid concentrations in turfgrass species (Zhang, 1997). These antioxidants may play a role in the regulation of plant.

Humic acid enhanced plant growth, increased yield, improved grade and marketability of garlic (Xin, 2006), and caused an improve in plant vegetative growth of onion ( Erik et al., 2000; El-Desuiki, 2004) Also, HA increased dry weight/ plant, total yield , N,P and K contents and uptake in tubers of potato (Ezzat et al., 2009 ; Mahmoud and Hafez, 2010). There are few researchers on using HA as foliar application. Foliar spray with HA significantly increased dry weight/ plant and green pod yield of snap bean ( Kaya et al., 2005 ; El- Bassiony et al., 2010) chlorophyll contents in leaf tissues of faba been ( El-Ghamry et al., 2009).

Scenedesmus is a genus of algae, specifically of the chlorophyceae. Scenedesmus is commonly found in the plankton of fresh water rivers, ponds and lakes, and sometimes in brackish. Scenedesmus is a small, nonmotile colonial green algae of cell aligned in a flat plate. The colonies most often have two or four cells, but may have 8,16 or rarely 32 and are occasionally unicellulart.

Fresh water green microalgae contain high percentage of macro and micronutrients bounded in their major biochemical constituents such as carbohydrates and protein (El-Fouly et al., 1992). In the area of agriculture and horticulture in the three genera microalgae from chlorophylla (Protococcus, Chlorella and Scenedesmus) have been shown to stimulate the growth of plant, due to the presence of auxine, cytokinins, gibberellins and related growth regulator substances (Ordog et al., 2004; Molnar and Ordog, 2005).

Foliar spray with extract of the green microalgae of Scenedesmus $s p$ as a new biofertilizer containing protein ( $50.56 \%$ ), N,P, K, Fe, Zn, Mn and $\mathrm{Cu}$ ( Shaaban et al., 2010) or with green microalgae extract obtained from Chlorella vulgars containing protein (35\%), fats (7\%), carbohydrates (9\%) and different amino acids as well as macro; i.e, $\mathrm{N}, \mathrm{P}, \mathrm{K}, \mathrm{Ca}, \mathrm{Mg}, \mathrm{Na}$ and micronutrients; i.e., $\mathrm{Fe}, \mathrm{Mn}, \mathrm{Zn}$ and $\mathrm{Cu}$ (Shaaban et al., 2001) increased N, P and K concentration and uptake by shoots and dry matter accumulation compared foliar spray with tap water. Also, spraying with green microalgae extract obtained from Chlorella ellipoida significantly increased chlorophyll $\mathrm{a}, \mathrm{b}$, and total $(\mathrm{a}+\mathrm{b})$ and showed 
strong positive correlation with increase in fresh weight, green weight and yield components of wheat plant (Abd El-Baky et al., 2008).

Therefore, the objective from this work was to evaluate the effect of foliar spray with humic acid (HA) and green microalgae extract (GMAE) obtained from Scenedesmus sp. on nutrient content and uptake as well as photosynthetic pigments. Consequently growth, yield and its components of garlic plant grown in sandy soil using drip irrigation system.

\section{MATERIALS AND METHODS}

The present work was carried out in vegetable Private Farm at ElKassasein Distract, Ismailia governorate during two successive winter seasons of 2008/2009 and 2009/2010, to evaluate the effect of foliar spray with both humic acid (HA) and green microalgae extract (GMAE) of Scenedesmus sp. as well as their interactions on nutrient content and uptake as well as photosynthetic pigments. Consequently growth and yield of garlic (sids-40) under sandy soil conditions using drip irrigation system. The physical and chemical analyses of the soil are presented in Table 1.

This experiment included nine treatments, which were the combinations between three concentrations of humic acid $(0,0.1$ and $0.2 \%)$ and three concentrations of green microalgae extract of Scenedesmus sp. ( 0, 0.1 and 0.2 $\%$ ). These treatments were arranged in a split plot in a complete randomized block design with three replicates. Humic acid concentrations were randomly arranged in the main plots and green microalgae extract concentrations were randomly distributed in the sub plots.

Humic acid (Mega Power-X) which was obtained from Union for Agriculture Development (UAD), Cairo, Egypt contain humic acid $19 \%$, folvic acid $2 \%$, free amino acid $5 \%$, chelated $\mathrm{Zn} 0.5 \%$, chelated $\mathrm{Fe} 0.025 \%$, chelated $\mathrm{Mn} 0.5 \%$ and potassium citrate $2 \%$.

Obtained green microalgae extract from Scenedesmus sp. (El-Sayed, 2004) was produced at the Algae Production Station of the National Research Centre (NRC, Giza, Egypt)) within three open ponds $\left(15 \mathrm{~m}^{3}\right.$ per each). Major components of the used green microalgae Scenedesmus sp. are shown in Table 2.

The cloves of garlic $c v$ sids 40 were sown on $1^{\text {st }}$ and $5^{\text {th }}$ October in the $1^{\text {st }}$ and $2^{\text {nd }}$ seasons, respectively. Garlic cloves were selected for uniformity in shape and size sown on both sides of the dripper lines at distance $10 \mathrm{~cm}$ a apart.

The experimental unit area was $12.6 \mathrm{~m}^{2}$. It contains three dripper lines with $7 \mathrm{~m}$ length each and $60 \mathrm{~cm}$ distance between each two drippers lines. One line was used for taking samples to measure the morphological, physiological traits and some chemical constituents and the other two lines were used for yield determinations. 
Table 1: The physical and chemical properties of soil during 2008/2009 and 2009/2010 seasons

\begin{tabular}{l|cc}
\hline \multicolumn{1}{c|}{ Characters } & \multicolumn{2}{c}{ Seasons } \\
\hline Physical properties & $\mathbf{2 0 0 8 / 2 0 0 9}$ & $\mathbf{2 0 0 9 / 2 0 1 0}$ \\
\cline { 2 - 3 } Sand (\%) & 93.5 & 92.6 \\
Silt (\%) & 1.7 & 1.6 \\
Clay & 4.8 & 5.8 \\
Texture & Sandy & Sandy \\
Chemical properties & & \\
pH & 8.17 & 8.09 \\
Organic matter(\%) & 0.03 & 0.07 \\
Available K (ppm) & 61 & 63 \\
Available P (ppm) & 6.4 & 6.9 \\
Available N (\%) & 6.7 & 7.2 \\
Calcium carbonate (\%) & 0.26 & 0.23 \\
Available Fe (ppm) & 5.13 & 4.67 \\
Available Zn (ppm) & 3.25 & 3.37 \\
Available Mn (ppm) & 2.07 & 2.18 \\
\hline
\end{tabular}

Table 2. Major constituents of the used green microalgae Scenedesmus sp.

\begin{tabular}{lc|cc|cc}
\hline Constituents(D.W) & $(\boldsymbol{\%})$ & \multicolumn{2}{|c|}{$\begin{array}{c}\text { Macronutrients } \\
(\%)\end{array}$} & \multicolumn{2}{|c}{$\begin{array}{c}\text { Micronutrients } \\
\text { (ppm) }\end{array}$} \\
\hline Crude protein & 50.56 & $\mathrm{~N}$ & 8.09 & $\mathrm{Fe}$ & 2057 \\
Ether extract & 7.39 & $\mathrm{P}$ & 2.69 & $\mathrm{Zn}$ & 722 \\
Crude fiber & 9.83 & $\mathrm{~K}$ & 0.65 & $\mathrm{Mn}$ & 747 \\
Ash & 9.18 & & & $\mathrm{Cu}$ & 93 \\
Moisture & 4.51 & & & & \\
\hline
\end{tabular}

Plants were sprayed three times by 15 days intervals, beginning 60 days after planting ( 60, 75 and 90 days) with both humic acid and green microalgae extract. Each plot received $2 \mathrm{~L}$ solutions of each concentrations using spreading agent in all treatments to improve adherence of the spray to the plant foliage for increasing humic acid (HA) and green microalgae extract (GMAE) absorption by the plants. The untreated plants (check) were sprayed with tap water and 
spreading agent. One dripper line was left between each two experimental plots without spraying as a gourd row to avoid the overlapping of spraying salutation.

All plots received equal amounts of farmyard manure at rate of 30 $\mathrm{m}^{3} /$ fed. and one third of all commercial fertilizers; i.e., ammonium sulphate $(20.5 \% \mathrm{~N})$, calcium superphosphate $\left(15.5 \% \mathrm{P}_{2} \mathrm{O}_{5}\right)$ and potassium sulphate (48 $\% \mathrm{~K}_{2} \mathrm{O}$ ) during soil preparation in the center of planting line, then covered by sand. These commercial fertilizers were added at the rates of 500, 450 and 200 $\mathrm{kg} / \mathrm{fed}$. respectively. The rest amounts of these fertilizers (two thirds) were splitted into 5 equal portions and added to the soil every 15 days, beginning one month after planting. The normal agricultural practices were carried out as commonly used in the district.

\section{Data Recorded}

\section{Content, Uptake and Total Uptake of N, P and $K$}

Dried represented samples of bulb and leaves of all tested treatments after 135 days from planting in both seasons were finely ground and wet digested. Then, N, P and K contents were determined according to the methods described by Bremner and Mulvaney (1982), Olsen and Sommers (1982) and Jackson (1970), respectively. The uptake of minerals and total plant uptake were calculated.

\section{Photosynthetic Pigments}

Disk samples from the fourth upper leaf were obtained after 135 days from planting in both seasons to determine chlorophyll $\mathrm{a}$ and $\mathrm{b}$ as well as carotenoids according to the method described by Wettestein (1957).

\section{Dry weight}

Ten plants were randomly taken from each plot after 135 days from planting, and they were divided separately into different organs; i.e., bulb and leaves, then they were oven dried at $70{ }^{\circ} \mathrm{C}$ tell constant weight. Dry weight was recorded as leaf and bulb dry weights/ plant $(\mathrm{g})$. In addition, total plant dry weight /plant (bulb +leaves) were calculated.

\section{Yield and its Components}

At proper maturity stage of bulbs (200 days after planting), bulbs in every plot were harvested and graded into three categories according to the Ministry of Economic for garlic exportation (1963) as follow: grade 1: Bulbs with diameter above $5.5 \mathrm{~cm}$, grade 2: Bulbs with diameter between $4.5-5.5 \mathrm{~cm}$ and grade 3: Bulbs with diameter less than $4.4 \mathrm{~cm}$. Then, each grade was weighed separately at the same harvest day and the following data were calculated as ton/ fed: total yield (grade $1+$ grade $2+$ grade 3 ). Also, average bulb fresh weight (gm) was recorded. 
Statistical Analysis: Collected data were subjected to statistical analysis of variance according to Snedecor and Cochran (1980), and means separation was done using L.S.D. at $5 \%$ level of probability.

\section{RESULTS AND DISCUSSION}

\section{Contents and Uptake of $\mathbf{N}, \mathbf{P}$ and $\mathrm{K}$}

\subsection{Effect of humic acid (HA)}

Concerning N,P and $\mathrm{K}$ contents, data in Table ${ }^{\top}$ show that foliar spray with HA ( Mega Power-X) at 0.1 or $0.2 \%$ increased N, P and K contents in bulb and leaves of garlic compared to control (sprayed with tap water) with insignificant differences between the two concentrations of HA in both seasons. On the other hand, spraying with HA had no significant effect on P content in bulb in the $2^{\text {nd }}$ season and $\mathrm{K}$ content in leaves in the $1^{\text {st }}$ season.

As for $\mathrm{N}, \mathrm{P}$ and $\mathrm{K}$ uptake and total uptake, presented data in Tables 4 and 5 show that garlic plants which were sprayed with HA at $0.2 \%$ recorded the maximum values of N,P and $\mathrm{K}$ uptake in bulb and N,P and $\mathrm{K}$ total uptake by plant followed by plants which sprayed with $\mathrm{HA}$ at $0.1 \%$.

Similar increases in the contents of some nutrients by foliar application with HA were obtained by Guvenc et al. (1999) who found that spraying lettuce plants with $\mathrm{HA}$ or Trisert-CB significantly increased $\mathrm{P}, \mathrm{K}, \mathrm{Na}$ and $\mathrm{Mg}$ contents compared to the control treatment.

These results are in accordance with those reported by Ezzat et al. (2009) and Mahmoud and Hafez (2010). They found that HA increased N,P and K contents and uptake by potato plants.

\subsection{Effect of green microalgae extract (GMAE)}

Respecting N, P and K content, the obtained results in Table 3 show that spraying garlic plants with GMAE obtained from Scenedesmus sp. at $0.2 \%$ recorded the maximum values of $\mathrm{N}, \mathrm{P}$ and $\mathrm{K}$ content in bulb and leaves with insignificant differences between GMAE at 0.2 and $0.1 \%$ for $\mathrm{P}$ content in bulb in both seasons.

As for $\mathrm{N}, \mathrm{P}$ and $\mathrm{K}$ uptake and total uptake, data in Tables 4 and 5 indicate that spraying with GMAE at $0.2 \%$ significantly increased N,P and K uptake in bulb and leaves and N,P and $\mathrm{K}$ total uptake by plant compared to control or GMAE treatment at $0.1 \%$ in both seasons.

The increase in $\mathrm{N}$ content in shoots may be due to that the high protein content $(50.56 \%$ on dry basis of the green microalgae extract of Scenedesmus sp.) which split natural plant amino acids involved directly in the metabolism. Plants can uptake $\mathrm{N}$ in forms of amino acids without relying on microbial mineralization (Lipson and Nasholm, 2001). Also the increase in N, P and $\mathrm{K}$ content in leaves and bulbs may be due to that the used green microalgae 
Table 3, 4 
ABOU EL-KHAIR et al.

Tables 5 and 6 
Scenedesmus sp. contained $8.09 \%$ N, $2.69 \% \mathrm{P}$ and $0.65 \% \mathrm{~K}$ on dry weight basis (El-Sayed, 2004). Nutrient uptake increases may be due to nutrients present in the cell extract of green microalgae (Scenedesmus sp.) which mostly are in an organic form and can be directly involved in the metabolism.

These results agree with those reported by Shaaban et al. (2001) who found that spraying of wheat plants with green microalgae extract increased N,P and $\mathrm{K}$ concentration and uptake by shoots and dry matter accumulation compared to foliar spray with tap water.

\subsection{Effect of HA $x$ GMAE}

It is apparent from data in Tables 6,7 and 8 that, the interaction between $\mathrm{HA}$ at $0.2 \%$ and GMAE at $0.2 \%$ was the superior treatment for increasing N,P and $\mathrm{K}$ content and uptake of bulb and leaves as well as N,P and $\mathrm{K}$ total uptake , followed by the interaction between $\mathrm{HA}$ at $0.1 \%$ and GMAE at $0.1 \%$ compared to control and other interaction treatments. On the other hand, in most cases, there were no significant differences among interaction treatments; i.e., $0.0 \mathrm{HA} \mathrm{x}$ $0.1 \%$ GMAE and 0.0 HA and 0.2\% GMAE with control (0.0 HA x 0.0 GMAE) on $\mathrm{N}, \mathrm{P}$ and $\mathrm{K}$ content and uptake in both seasons.

\section{Photosynthetic Pigments}

\section{1.Effect of $\mathrm{HA}$}

It is intelligible from data in Table 9 that the garlic plants which were sprayed with HA at 0.1 and $0.2 \%$ significantly increased the concentrations of chlorophyll $\mathrm{a}, \mathrm{b}$, total $(\mathrm{a}+\mathrm{b})$ and carotenoides in leaf tissue in the $2^{\text {nd }}$ season only compared to plants which unsprayed. Spraying with HA at $0.2 \%$ recorded the maximum values of chlorophyll $a, b$, total $(a+b)$ and carotenoids. Humic acid enhanced photosynthetic process and development of chlorophyll (Liu et al., 1998).

The increase in chlorophyll through foliar spray with HA may be due to that HA content $2 \%$ free amino acids that would help to increase chlorophyll concentration in plant leading to higher degree of photosynthesis.

Similar findings were obtained by El-Ghamry et al. (2009). They found that foliar spray with HA increased chlorophyll contents in leaf tissues of faba been.

\subsection{Effect of GMAE}

It is obvious from data in Table 9 that spraying garlic plants with GMAE at 0.1 and $0.2 \%$ significantly increased the concentrations of chlorophyll $a, b$ and total $(\mathrm{a}+\mathrm{b})$ in leaf tissues in the second season and carotenoides in leaf tissues in both seasons compared to plants which unsprayed. Also, spraying with GMAE at $0.2 \%$ recorded the maximum values of photosynthetic pigments in leaf tissues. 
ABOU EL-KHAIR et al.

7 and 8 
Tables 9 and 10 
These results are in harmony with those reported by Abd El-Baky et al. (2008) who found that spraying with green microalgae extract obtained from Chlorella ellipoida significantly increased chlorophyll a, b, and total $(\mathrm{a}+\mathrm{b})$ in leaf tissues of wheat.

\subsection{Effect of HA $x$ GMAE}

The obtained data in Table 10 show that the interaction between HA at $0.1 \%$ and GMAE at $0.1 \%$ or the interaction between HA at $0.2 \%$ and GMAE at $0.2 \%$ were the best interaction treatments for increasing concentration of chlorophyll $\mathrm{a}, \mathrm{b}$ and total $(\mathrm{a}+\mathrm{b})$, whereas the interaction between $\mathrm{HA}$ at $0.2 \%$ and GMAE at $0.2 \%$ was the best interaction treatment for increasing carotenoides in leaf tissues in the second season only.

\section{Dry weight \\ 3.1 Effect of $\mathrm{HA}$}

The obtained results in Table 11 show that spraying garlic plants with HA at 0.1 or $0.2 \%$ significantly increased dry weight of leaves, bulb and total (leaves + bulb) / plant compared to control (sprayed with tap water). Foliar spray with $\mathrm{HA}$ at $0.2 \%$ recorded the maximum values of dry weight of leaves and total (leaves + bulb) with insignificant differences could be detected with HA at $0.1 \%$ with respect to dry weight of leaves and total dry weight. The increases in total dry weight/ plant were about 0.96 and $1.84 \mathrm{gm} /$ plant for spraying with HA at 0.2 $\%$ and 0.62 and $1.34 \mathrm{gm} /$ plant for spraying with $\mathrm{HA}$ at $0.1 \%$ over the control in the $1^{\text {st }}$ and $2^{\text {nd }}$ seasons, respectively.

The role of HA in plant growth may be due to that HA stimulated plant growth through increasing cell division, as well as optimizing uptake of nutrients and water (Atiyeh et al., 2002 ; Chen et al., 2004) . Also, regulate hormone level, improve plant growth and enhance stress tolerance (Piccolo et al., 1992).

The increment in growth parameters may be due to that HA is extremely important component because its constituents a stable fraction of carbon, thus regulating the carbon cycle and release of nutrients, including N,P, and S, which decrease the need for inorganic fertilizer for plant growth. Humic acid stimulate plant growth by assimilation of major and minor elements, enzymes activation and /or inhibition, changes in membrane permeability, protein synthesis and finally the activation of biomass production (Ulukan, 2008).

Humic acid is excellent foliar fertilizer carrier and activator. Application of HA as foliar spray can improve the growth of plant foliage, roots and fruits. By increasing plant growth process within in leaves an increase in carbohydrates content of the leaves and stem occurs. These carbohydrates are then transported down the stems into the roots where they are in part released from the root to provide nutrients for various soil microorganisms on the rhizosplane and in the rhizosphere. The microorganisms then release acids and other organic 
compounds which increase the availability of plant nutrients. Other microorganisms release hormone like compounds which are taken up by plant roots.

Similar increases in plant growth by application of HA as foliar spray were obtained by Padem et al. (1999) on pepper and eggplant, Erik et al. (2000) on onion, Kaya et al. (2005) and El- Bassiony et al. (2010) on snap been.

\subsection{Effect of GMAE}

It can be seen from data in Table 11 that foliar spray with GMAE at 0.2 $\%$ was the best treatment for enhancing dry weight of leaves, bulb and total (leaves + bulb) / plant. The increases in total dry weight/ plant were about 2.16 and $1.74 \mathrm{gm} /$ plant for spraying with GMAE at $0.2 \%$ over the control (sprayed with tap water) in the $1^{\text {st }}$ and $2^{\text {nd }}$ seasons, respectively.

The three genera microalgae from chlorophylla (Protococcus, Chlorella and Scenedesmus) have been shown to stimulate the growth of plant, due to the presence of auxine, cytokinins, gibberellins and related growth regulator substances (Ordog et al., 2004; Molnar and Ordog, 2005).

\subsection{Effect of HA $x$ GMAE}

It is marked from data in Table 12 that the interaction between HA at 0.2 $\%$ and GMAE at $0.2 \%$ was the superior interaction treatment for increasing dry weight of leaves, bulb and total/ plant, followed by the interaction between HA at $0.1 \%$ and GMAE at $0.2 \%$ compared to control and other interaction treatments in both seasons. The increases in total dry weight/ plant were about 2.16 and $3.72 \mathrm{gm} /$ plant for the interaction between spraying with HA at $0.2 \%$ and GMAE at $0.2 \%$ and 0.78 and $3.14 \mathrm{gm} /$ plant for the interaction between spraying with $\mathrm{HA}$ at $0.1 \%$ and GMAE at $0.2 \%$ over the control ( sprayed with tap water) in the $1^{\text {st }}$ and $2^{\text {nd }}$ seasons, respectively.

Amino acids derived from proteolysis of proteins in green microalgae extract and HA contain $2 \%$ amino acids that would have a chelating effect on micronutrients when applied and consequently make the absorption and transportation of micronutrients inside the plant is easier due to its effect on cell membrane permeability. Some of these micronutrients play roles in synthesis of intermediates in the metabolic pathway, through tryptophane to auxin (Ohki, 1978). Consequently auxin lead to increase in vegetative growth and increase in total phenol, calcium content and activity of chatecol oxidase, these materials protect plants against pathogen stress (Chowdhury, 2003). 
Tables 11 and 12 


\section{Yield and Its Components 4.1. Effect of $\mathrm{HA}$}

It is visible from data in Table 13 that foliar spray of garlic plants with $\mathrm{HA}$ at 0.1 or $0.2 \%$ significantly increased average bulb weight, yield of grades 1 and 2 as well as total yield/fed. compared to control (sprayed with tap water) and $\mathrm{HA}$ at $0.2 \%$ recorded maximum values of average bulb weight, yield of grades 1 and 2 as well as total yield/feddan. On the other hand, spraying with HA at different concentrations had no significant effect on yield of grade 1 and yield of grade 3 in the $2^{\text {nd }}$ season and HA at $0.2 \%$ recorded the maximum values of yield of grade 3 in the $2^{\text {nd }}$ season. The increases in total yield/fed. were about 1.269 and $0.711 \mathrm{ton} / \mathrm{fed}$. for spraying with HA at $0.2 \%$ and 0.721 and 0.675 ton/fed for spraying with HA at $0.1 \%$ over the control ( sprayed with tap water) in the $1^{\text {st }}$ and $2^{\text {nd }}$ seasons, respectively.

Foliar spray with HA at 0.1 or $0.2 \%$ was superior in increasing N,P and $\mathrm{K}$ content and uptake (Tables 3, 4 and 5), photosynthetic pigments (Table 9). As a reflection to dry weight of shoots (Table 11) and total yield of garlic (Table 13).

Obtained results are in harmony with those reported by El-Desuki (2004) on onion, Xin (2006) on garlic, Ezzat et al. (2009), Mahmoud and Hafez (2010) on potato. They found that application of HA as foliar spraywere improved and increased total yield.

\subsection{Effect of GMAE}

The obtained results in Table 13 show that plants which sprayed with GMAE at different concentrations $(0.1$ and $0.2 \%)$ reflected a significant effect on average bulb weight and yield of grades 1 and 2 as well as total yield/fed. compared to the plants which unsprayed and spraying with GMAE at $0.2 \%$ recorded the maximum values of these characters. On the other hand, spraying with GMAE had no significant effect on yield of grade 3 in the $1^{\text {st }}$ season and spraying with $0.2 \%$ recorded the minimum value of yield of grade 3 with insignificant differences with GMAE at $0.1 \%$ in the $2^{\text {nd }}$ season. The increases in total yield/fed. were about 0.778 and 0.676 ton/ fed. for spraying with GMAE at $0.2 \%$ and 0.381 and 0.505 ton/fed. for spraying with GMAE at $0.1 \%$ over the control ( sprayed with tap water) in the $1^{\text {st }}$ and $2^{\text {nd }}$ seasons, respectively.

Foliar spray with GMAE of Scenedesmus sp. at 0.1 or $0.2 \%$ was superior in increasing N,P and K content and uptake (Tables 3,4 and 5), photosynthetic pigments (Table 9). As a reflection to dry weight of shoots (Table 11) and total yield of garlic (Table 13).

These results are in harmony with those obtained by Abd El-Baky et al. (2008). They found that spraying with green microalgae extract obtained from Chlorella ellipoida significantly increased green weight and yield component of wheat. 
Tables 13 and 14 


\subsection{Effect of HA $x$ GMAE}

It is clear from data in Table 14 that the interaction between HA at $0.2 \%$ and GMAE at $0.2 \%$ was the best interaction treatment for increasing average bulb weight, yield of grades 1 and 2 and total yield/fed. followed by the interaction between spraying with $\mathrm{HA}$ at $0.1 \%$ and GMAE at $0.2 \%$. On the other hand, the interaction between HA and GMAE had no significant effect on yield of grade 3 in the $1^{\text {st }}$ season and the interaction between spraying with $\mathrm{HA}$ at $0.2 \%$ and GMAE at $0.2 \%$ recorded the minimum value of yield of grade 3 in the $2^{\text {nd }}$ season. There were no significant differences among the interactions treatments, i.e., $0 \mathrm{HA} \times 0.1 \%$ GMAE and $0 \mathrm{HA} \times 0.2 \%$ GMAE with control ( 0 HA x 0 GMAE) in the most cases.

The increases in total yield/fed. were about 2.121 and 1.472 ton /fed. for the interaction between spraying with $\mathrm{HA}$ at $0.2 \%$ and GMAE at $0.2 \%$ and 0.900 and 1.214 ton/fed for the interaction between spraying with HA at $0.1 \%$ and GMAE at $0.1 \%$ over the control (sprayed with tap water ) in the $1^{\text {st }}$ and $2^{\text {nd }}$ seasons, respectively.

Conclusively, from foregoing results of this study, it could be concluded that spraying of garlic plants with $\mathrm{HA}$ at $0.2 \%$ and GMAE at $0.2 \%$ increased mineral uptake, plant growth and total yield of garlic under sandy soil conditions.

\section{REFERENCES}

Abd El-Baky, H.H. M.M.Hussein and G.S. El-Baroty 2008. Algal extracts improve antioxidant defense abilities and salt tolerance of wheat plant irrigated with sea water. Electronic J. Environ., Agric. and Food Chem., 7 (4);2821-2832.

Atiyeh, R.M., S. Lee, C.A. Edwards, N.Q. Arancon, and J.D. Metzger 2002. The influence of humic acids derived from earthworm processed organic wastes on plant growth. Bioresource Technology, 84: 7-14.

Bremner, J. M., and C. S. Mulvaney 1982. Total nitrogen. In: Page, A. L., R. H. Miller, and D. R. Keeney (Eds). Methods of Soil Analysis. Part 2, Amer.Soc.Agron.Madison, W. I. USA. pp. 595- 624.

Chen, Y., M. De Nobili and T. Aviad 2004. Stimulatory effect of humic substances on plant growth. In "Soil Organic Matter In Sustainable Agriculture".(Eds F. Magdoff, R.R. Weil). 103-130, Boca Raton, FL.

Chowdhury, A.K. 2003. Control of Sclerotium bilight of groundnut by plant growth substances. Crop Research (Hisar), 25: 355-359.

El-Bassiony, A.M., Z.F. Fawzy, M.M.H. Abd El-Baky, and A. R. Mahmoud 2010. Response of snap bean plants to mineral fertilizers and humic acid application. Res. J. Agric. and Bio. Sci., 6 (2): 169-175. 
EL-Desuki, M. 2004. Response of onion plants to humic acid and mineral fertilizers application. Annals of Agric. Sci., Moshtohor, 42(4): 19451964

El-Fouly, M.M., F.E. Abdalla, and M.M. Shaaban 1992. Multipurpose large scale production of microalgae biomass in Egypt. Proc. 1st Egyptian Etalian Symp. on Biotechnology, Assuit, Egypt (Nov., 21-23, 1992), pp. 305-314.

El-Ghamry, A. M., K. M. Abd El-Hai, and K.M. Ghoneem 2009. Amino and Humic Acids Promote Growth, Yield and Disease Resistance of Faba Bean Cultivated in Clayey Soil. Aust. J. Basic \& Appl. Sci. , 3 (2): 731-739.

El-Sayed, A.B. 2004. Screening and growth characterizations of the green life stock of drill water from Jeddah I-Isolation and growth characteristics of Scenedesmus sp. N. Egypt. J. Microbiol. , 8:376-385.

Erik, B. G., Feibert, C. C. Shock, and L. D. Saundres 2000. Evaluation of humic acid and other non conventional fertilizer additives for onion productivity. Malheur Experiment Station, Oregon State University Ontario, OR, 2000.

Ezzat, A. S., U. M. Saif Eldeen, and A. M. Abd El-Hameed.2009. Effect of irrigation water quantity, antitranspirant and humic acid on growth, yield, nutrients content and water use efficiency of potato (Solanum tuberosum L.). J. Agric. Sci., Mansoura Univ., 34 (12): 11585 - 11603.

Guvenc, I., A. Dursun, and M. Turan 1999. Effects of different foliar fertilizers on growth, yield and nutrient content components of lettuce and crisp lettuce . Acta Hort. , 486, 247-252.

Jackson, M. L. 1970. Soil Chemical Analysis . New Jersey, Prentice Hall Inc. Page 498.

Kaya, M., M. Atak, K.M. Khawar, C.Y. Cftc and S. Ozcan 2005. Effect of pre-sowing seed treatment with zinc and foliar spray of humic acid on yield of common bean (Phaseolus vulgaris L.). J. Plant Res., 118:207214.

Lipson, D.A. and T. Nasholm 2001. The unexpected versatility of plants: Organic nitrogen use and availability in terrestrial ecosystems. Oecologia, 128:305-316.

Liu, C. R., J. Cooper, and D. C. Bowman 1998. Humic acid application affects photosynthesis, root development and nutrient content of creeping bentgrass, Hort. Science, 33: 1023-1025.

Mahmoud, A. R. and M. M Hafez 2010. Increasing productivity of potato plants (Solanum tuberosum L.) by using potassium fertilizer and humic acid application. Int. J. Acad. Res., March, Vol. 2 (2): 83-88. 
Ministry of Economy, Egypt 1963. To control exported garlic. Ministerial order No.652.

Molnar, Z. and V. Ordog 2005. The effect of cyanobacterial compounds on the organogenesis of pea cultured in vitro. Acta Biologica Szegediensis, 49: 37-38.

Ohki, K. 1978. Zinc concentration in soybean as related to growth, photosynthesis, and carbon anhydrase activity. Crop Sci., 18:79-82.

Olsen, S. R., and L. E. Sommers 1982. Phosphorus. In: Page. A. L., R. H. Miller, and D. R.Keeney (Eds). Methods of Soil Analysis .Part 2 Amer. Soc. Agron. Madison, W. I. USA. pp. 403-430.

Ordog, V., W.A. Stirk, V. Staden, O. Novak, and M. Strand 2004. Endogenous cytokinins in three genera microalgae from chlorophyta. J. Phycol., 40: 88-95.

Padem, H ., A . Ocal, and R . Alan 1999 . Effect of humic acid added to foliar fertilizer on quality and nutrient content of eggplant and pepper seedlings. Acta Hort. , 486: 241- 246.

Piccolo, A., S. Nardi, and G. Concheri 1992. Structural characteristics of humic substances as regulated to nitrate uptake and growth regulation in plant systems. Soil Biochem., 24: 373-380.

Senn, T.L. 1991. Humates in Agriculture. Acres USA, Jan.

Shaaban, M.M. 2001. Green microalgae water extract as foliar feeding to wheat plants. Pakistan Journal of Biological Sciences , 4 (6): 628-632

Shaaban,M. M, A. M. El-Saady, and A. B. El-Sayed 2010. Green microalgae water extract and micronutrients foliar application as promoters to nutrient balance and growth of wheat plants. J. Amer. Sci., 9 (6):631-636.

Snedecor, G.W., and W.G.Cochran 1980. Statistical Methods. $7^{\text {th }}$ ed. Iowa State Univ., Press, Ames., Iowa, U.S.A.

Ulukon, H. 2008. Effect of soil applied humic acid at different sowing times on some yield components in wheat (Triticum spp.) hybrids. Int. J. Bot., 4 (2): 164-175.

Wettestein, D. 1957. Chlorophyll Lethale un der Submikroskopische Formwechsel der Plastiden. Exptl. Cell Reso. , 12:427-506.

Xin, W. 2006. The Effects of Active HA-organic Fertilizer on Garlic Growth. www. en. cnki.cn/article-en CJFDTOTAL.

Zhang, X. 1997. Influence of plant growth regulators on turfgrasss growth, antioxidant status, and drought tolerance. Ph.D. Thesis, Faculty Of Virginia Polytechni (Institute and State University). 


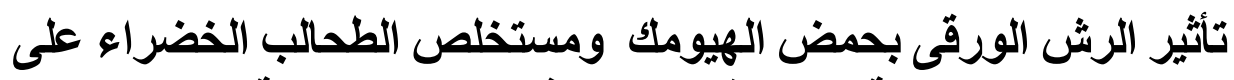
نمو وإنتاجية نبات الثوم النامى في الارض الرمبن الرملية

السيد السيد أبو الخير' ، ابراهيم عبد الله سليم العسيلى ' ، هانى السيا محمد اسماعيل' البيل

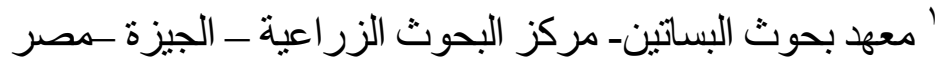
2 قسم البساتين- كلية الزر اعة - جامعة الزقازيق

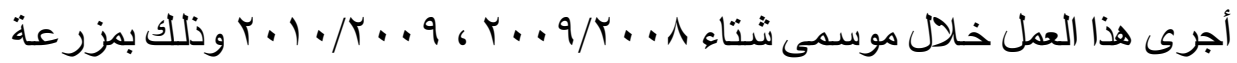

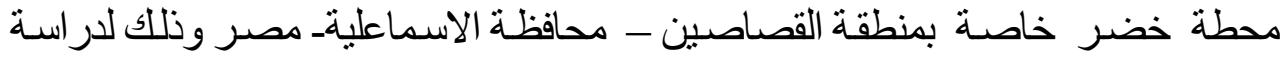

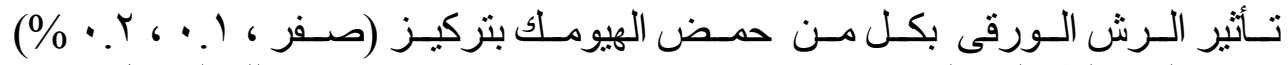

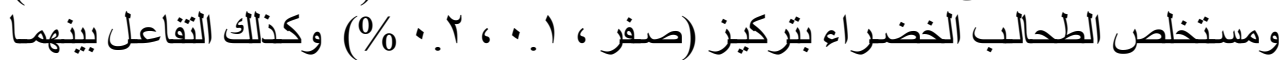

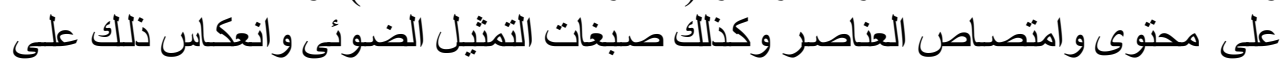

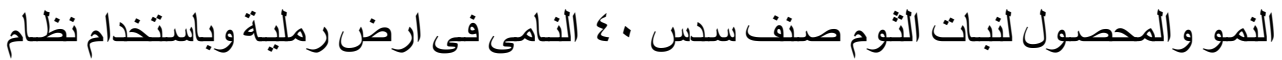
الرى بالتنقيط. - اليط

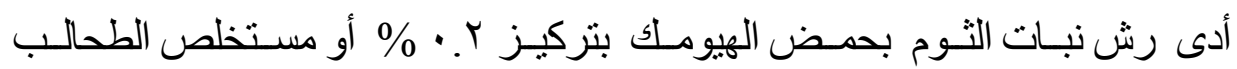

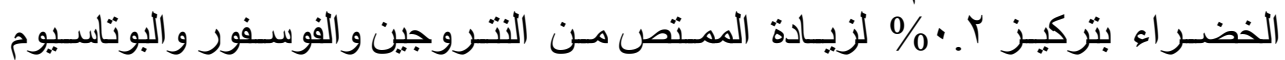

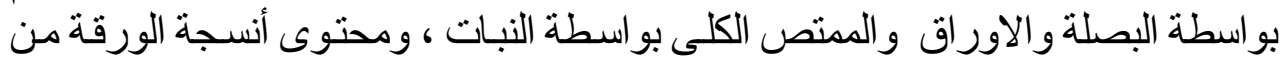

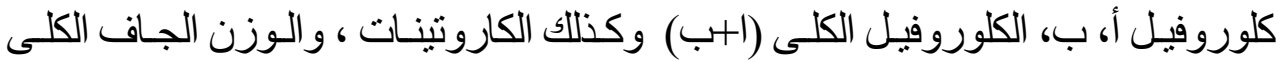

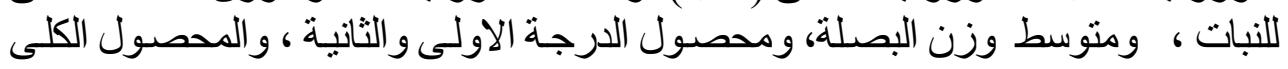

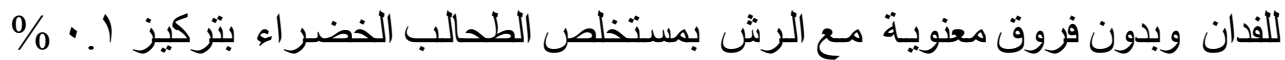
بخصوص المحصول ومكوناتها.

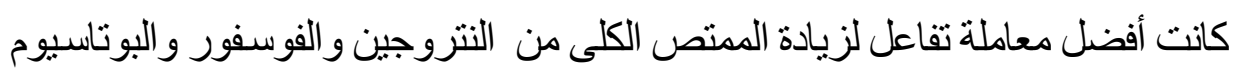

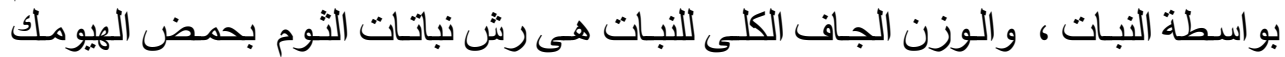

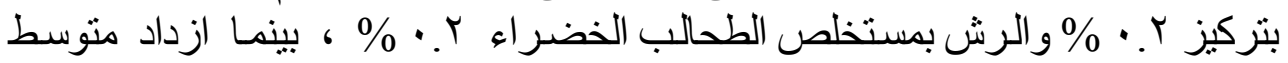

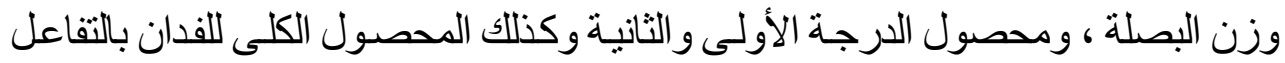

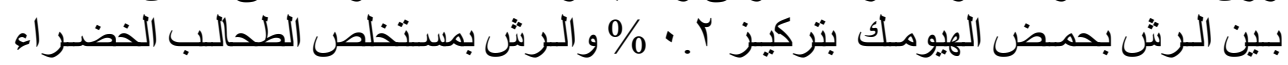

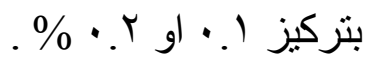

